\title{
Appraisal of Widows Support Groups in Contemporary Societies: A Study of Widows in Ota Metropolis
}

\author{
Tayo 0. George \\ Department of Sociology, Covenant University, P. M. B. 1023, Ogun State, Nigeria \\ Jonathan A. Odukoya
}

Department of Psychology, Covenant University, P. M. B. 1023, Ogun State, Nigeria

\author{
Albert 0. Shaibu \\ Department of Religious Studies, Kogi State College of Education, Ankpa, Nigeria
}

Onyekwere O. C. Uche

Department of Religious Studies, Nnamdi Azikiwe University, P.M.B 5025, Awka, Nigeria

Dare 0. Omonijo

(Corresponding Author), Department of Sociology and Anthropology, Obafemi Awolowo University, lle Ife, Nigeria E-mail: omonijoojo@yahoo.com or ukamaka.omonijo@gmail.com

Doi:10.5901/mjss.2016.v7n5p158

\section{Abstract}

This paper examined the nature and quality of support rendered to widows during and after the mourning period by support groups in Ota. The role of support groups ranging from family members, friends, associations, religious institutions in widows' wellbeing was examined using survey questionnaire and in-depth interview. Findings from the study informed the basis for conclusion and recommendations for policy making and implementation at individual(s), groups, local, state and national levels in Nigeria.

Keywords: Appraisal, widows, support groups, contemporary, wellbeing

\section{Introduction}

Dwelling on Martin Luther King Jnr., the essence of life is to stand by others during difficulties and not during coziness (African Leadership 2012). This historic statement could be used to explain the nature of mankind in both developed and underdeveloped countries with the aim of drawing a comparison. In the former, it is evident in the literature that policies of government are usually packaged to assist the less-privileged (Millennium Development Goals, 2015; United Nations Development Programme, 2015) while in the later, robust policies to make life easy for mankind are never considered a priority. Where policies are available they are often designed to make life difficult for the masses (Vanguard, 2015).

In developed nations, apart from using the state resources to assist the poor, past studies also confirm that the lifestyle of many leaders, their wives and the elite class is hinged on assisting the less privileged globally (The Looma Foundation, 2015a, Bill and Melinda Gates Foundation New York Times (2016), Mark Zuckerberg Foundation Callahan, (2016) while the elite class in Third World countries are known for siphoning the resources of the state (Steele, 2000; Andelman, 2007; World Bank, 2013) to the detriment of the same set of people. Sad enough, many elites who have business ventures in Third World countries are known for using the same avenues to enslave and exploit their fellow human being (the poor masses). Hence, while such elites are getting richer, their workers are getting poorer due to poor remunerations and lack of fringe benefits.

Given the above, articles directed at the pathetic situations of the less-privileged in developed nations have been fully expressed in the literature (Annie, 2006; Daily Mail, 2007; Clark, 2007; BBC Children in Need, 2012; Brunnstrom and 
Mason, 2015) while in most countries sub-Saharan Africa (SSA) little is known in the literature on effective and efficient government policies channeled at improving the plights of the less-privileged. Moreover, articles exploring the lifestyle of their leaders in assisting the poor are very scarce in the literature.

This is not surprising, anyway, since it has been established severally, that leaders in Third World countries are modern Nero's in brutality and self-indulgence, tyranny and oppression (West, 2003), it, therefore, becomes practically impossible for them to improve the lots of their citizens, in spite of the enormous natural and human endowments (African Leadership 2012) in the region. Hence, it could be noted that the heart that seeks after the good of the public has eluded the majority of leaders in most Third World countries. Their main purpose of wanting to exercise power is to satisfy their selfish interests (Okonkwo, 2007; Ogbeidi, 2012), instead of seeing to the need of the less-privileged.

Nigeria is one of such nations in West Africa, where many elites apply 'I don't care attitude' to state affairs, the situation of widows inclusive. The nonchalant attitude of the elite class to several issues demanding the state responsiveness in Nigeria is prevalent and it has become a sort of concern to scholars across the nation. More often than not, several problems affecting the masses, including widows, are treated with levity. Even in tertiary institutions, where sensitive issues such widowhood ought to have been fully explored, little was known in the literature for many years in the past. In other words, the plights of widows were ignored in the academic literature for many years (George, Omonijo, Uche, Anyaegbunam and Shaibu 2016).

However, the recent literature shows that the socio-economic problems of widows are gradually becoming issues of discussion in academia (Sesay and Odebiyi, 1998; Tamale, 2004; Sossou, 2002; Ssenyonjo, 2007; Tamale, 2008; Oyeniyi and Ayodeji 2010; Samuel, 2011; Durojaye, 2013; Adeyemo, 2013). Nevertheless, none of the above studies harnessed widows supporting groups, which could be very useful in assessing the type of help available for them in Nigeria. Although the study of George, et al., (2016) dealt with problems of widowhood among the Aworis in southwest geo-political zone of Nigeria, the study ignored widows supporting groups and the effects of such supporting groups on the lives of widows in the same study area. This study was therefore conceived to address these gaps in knowledge. The study intends to: (i) identifying the types of support received by widows, (ii) ascertain the impact of educational attainment on widows' wellbeing and, (iii) determine the effecs of the support received on widows' wellbeing in Ota Metropolis.

The paper proceeds in the following order: Introduction, literature review, methodology, summary of findings, recommendations, and concluding remarks.

\subsection{Definition of Terms}

Widowhood- this means a state or condition of being a widow.

Widows' wellbeing, in this context, implies access and availability of material and non-materials resources that make life comfortable and good for the affected widow.

Third World Countries-Underdeveloped nations

\subsection{Concepts of Support Groups and Widows' Well-being: An Overview}

The concept of Support Groups has varied meanings in literature. In this paper, support groups refer to individuals, groups, associations, organizations or platforms through which widows in a given society receive assistance. The assistance ranges from materials (cash, clothing, food, shelter, medication etc.) to non-material assistance such as emotional support, counselling, care, lending a helping hand in terms of washing, preparing food, cleaning, companionship, etc.

Further to the above, past studies show that there are variations in the amounts and the kinds of assistance or support sources that are available for widows Potash (1986), for instance noted that apart from the help given by children and sometimes natal kin, widows generally receive little or no income support, but may receive some labour assistance. The view of Potash, (1986) could be applied to the traditional societies where, people used to perceive themselves as their brothers' keepers.

Also, some widows especially those who are still of marriageable age, are encouraged to remarry as a coping response for widowhood while those who are not too young rely on their older children, family members, relatives, friends and religious organizations (such as churches and mosques) and their employment or vocation for financial support.

However, apart from the selfishness of quite a lot of persons in Nigeria today, the present economic crises, increasing level of unemployment among the populace, and the high rate of inflation partly account for why most families are unable to extend financial support to widows. In spite of the foregoing, some notable private and non-governmental 
organizations (NGOs) within and outside Nigeria have brought succor and smile to the faces of widows in various capacities, even though a lot more still needs to be done.

\subsection{Examination of Research on Widows Support Groups and Widows' Well-being Globally}

The concerned for the less privileged is never treated with levity in many developed societies. Unlike many Third World countries where the less privileged, more often than not, are treated like 'a keg of toxic' waste, welfare and other supporting programmes for the less privileged have been reflecting in the programmes and the lifestyle of the majority of leaders in developed societies Blair (2010), for the past many decades.

Rostow, (1960) is a reflection of the above viewpoint. His thesis clearly demonstrates how the wealth of many developed nations is being used to assist the poor. Dwelling on the last stage of development mentioned above, 'the age of mass consumption' nations that have actually developed are characterized by prosperity and abundance. It is a period in which the society is known for affluence but not marked by visionless leaders, known for boasting that money is not the problem of their countries, but how to spend it. Rather, it is a period when leaders, who have foresight plan for their countries and invest the state resources on profitable venture that will ultimately result in industrialization. Moreover, the period is not associated with massive embezzlement of the public fund and stockpiling the loot in foreign banks by the elites in power, as obtainable in many underdeveloped societies, but it is a period of making positive impacts on the lives of the less privileged in their countries.

Apart from attending to the needs of the less privileged in their countries, leaders of developed nations are also known for assisting underdeveloped nations, through foreign aids (Wogu, Duruji and Ibietan, 2014). The North America and Western Europe belong to this category (Rostow, 1960). The former Soviet Union of Soviet Socialist Republic (USSR) also utilized its wealth to build global power and influence in Cuba, Libya, Ukraine and other socialist countries.

Given the above, several foundations and supporting groups exist in developed nations to cater for the less privileged (Age Concern, 1999; UK International Development Committee, 1999; Owen, 2000; World Bank, 2000; The World's Women 2000; Human Rights Watch, 2006; Women's Rights, 2007). Widows constitute a significant number of this class of people. Probably that could be the main reason why Bliar, $(2010$, P. 1) regard them as "a hidden humanitarian crisis globally".

Hence, it has become expedient to address the numerous problems confronting widows globally with the aim of providing lasting solutions to their pathetic situations. The foregoing has actually informed the formation of laws locally, several treaties and resolutions, specially designed by the local and global organizations such as the constitution, United Nations, African Union.

Quite unfortunate, while the above resolutions have been fully implemented with attendant proofs of positive improvements in the lives of widows in developed nations, failure to implement the same has resulted in deplorable conditions for widows in many Third World countries, Nigeria inclusive.

However, some of the widows supporting groups and their activities in both developed and Third World countries are briefly discussed below.

\subsection{Exposition of Research on Widow Supporting Groups in Developed Nations}

Previous studies show that widows supporting groups exist in large number in developed nations (United Nation's Division for the Advancement of Women, 2000; Trivedi, Sareen \& Dhyani, 2009; Widows Connection, 2014; Way Widowed and Young, 2014; New Covenant for Widows, 2016; National Widowers Organisation, 2016). These groups have contributed significantly to the lives of widows not only in developed nations but also in many Third World societies. However, just a few of them that speak to the topic under study are succinctly discussed below:

\subsubsection{World Care Worldwide (WCW)}

This is one of the supporting groups in developed nations that are committed to the plight of the widows. The organization is located in the United Kingdom. It includes Communities of Health $(\mathrm{COH})$ group, involving local and international organisations. Since its inception in 2002, WCW has recorded the following achievements:

- In 2006, the body received the first Community Champions Award Fund from Scarman Trust Scarman Trust, (2015).

- In 2007, it was able to rent an office at Froud Centre and developed a programme known as Digital Story Telling for Children Myers, (2012). This was supported by Local Network Fund (Scarman Trust, 2015). 
- In 2008, WCW developed its first programme with the aim of craving the indulgence of the public to the plight of widows. The programme was supported with food items, distributed to 120 widows in the Niger Delta, Nigeria (Widow Care Worldwide, 2015). The fund used for the programme was donated by the founder of WCW, the Trustees and friends (see fig. 1 below) Widow Care Worldwide, (2015)

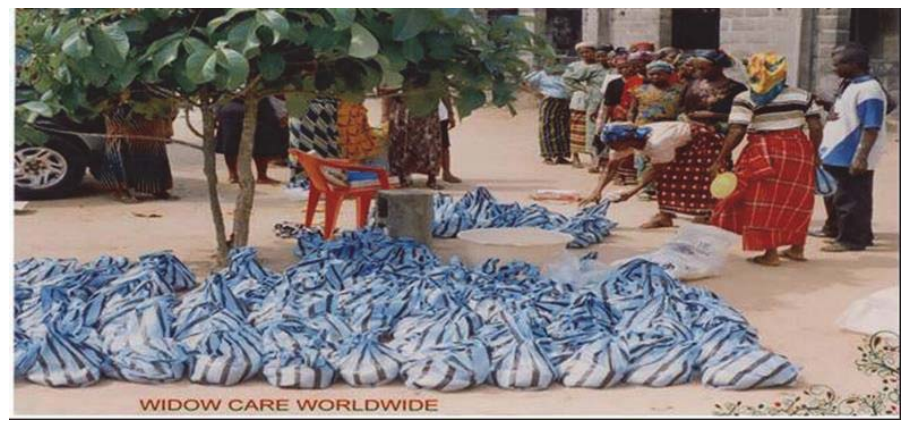

Figure 1: Widow Picking up their Supporting Materials

Source: Widow Care Worldwide, (2016)

- In 2009, through the help of the Newham Grass Root Fund NGRF, (2015) this organization developed young widows project of outreach where individuals received information and skill development programmes. Also, it 'delivered workshop sessions with a group of young single mothers in Southwest London about the plight of widows in Nigeria (NGRF, 2015).

Dwelling on the above, it could be observed that the influence of WCW on widows is not limited to one country (the United Kingdom) alone, widows in many Third World countries such as Nigeria have benefited from her programmes (see fig 1), which is impressive. Nevertheless, it has also been discovered that widowers are excluded from their impactful activities. Although, it has been argued that the problem of widowhood affects women more than men Trivedi, et al., (2009) but there are a few situations where men could be affected psychologically, emotionally, socially and economically than women. For instance, the death of a woman who was the breadwinner of her family while alive could adversely affect her husband. In some families also, women are the backbone of their husbands (Andrea-Teresa, 2010). When such women die suddenly the loss may affect their husbands negatively. Such persons (husbands) need to be encouraged to move on in life. Given this flaw in knowledge, another widow supporting organization known for assisting the widowers is discussed below:

\subsubsection{Widowed Persons Support Group (WPSG)}

This is also a Methodist non-profit orgainsation created to assist the widows (Light, 2014). Members of this group according to this reporter meet once in a month for meals and card games.

Presently, Light (2014) reported that this group is not limited to helping widows alone, widowers are also beneficiaries. She argues further that the orgainisation has helped over four hundred widowers since its inception. She also believes that members, from 50 s to 90 s are recruited from church programmes and funeral homes to serve in this organisation. One unique thing about this body is that members are drawn from different religion backgrounds (Christianity, Jewish, Islam and Hindus).

Having examined the above widows supporting groups and their contributions to making life easy for widows and widowers, it could be observed that their programmes excluded the children of widows and widowers. More often than not, many widows and widowers use to have many children which they may not be able to train or cater for. The failure to include them in various programmes designed to assist their mothers and fathers could be regarded as a major flaw which should not be easily overlooked. The social problem associated with widows and widowers children is not only restricted to their mothers and fathers, but to the society at large. This is because if their children are not properly attended to the probability of them diverting to social evils (prostitution, armed robbery, kidnapping, Advanced-Fee-Fraud popularly known as 419 , internet fraud known as yahoo yahoo boys etc.) in order to cater for themselves, could be very 
high, in a backward society like Nigeria where poverty rate is very high Adeniran, (2008) cited by Daniel, (2015). Moreover, social ills emanated from such children, if escalated, could create more tension for a security risk nation like Nigeria.

Moreover, the above NGOs failed to consider the promotion of widows' fundamental human rights a priority. One of the best ways to empower women is through enlightenment programmes. Such programmes could keep them abreast of their fundamental human rights and it may enable some of them to fight for their rights when deprived. It is unfortunate to realise that that many widows in many Third World countries are illiterates Wadri, (2004) and therefore ignorant of their rights. Any NGO that therefore enlightened the widows of such human rights would be contributing significantly into their lives. It is on these grounds that the authors of this paper consider The Loomba Foundation that tackles the above mentioned flaws in knowledge fit for this study.

\subsubsection{The Loomba Foundation (TLF)}

This body was established in Britain as a non-profitable organization. It "has sister charities registered in India and the USA. The inspiration came from Raj's late mother, Shrimati Pushpa Wati Loomba, who became a widow at the early age of 37 and succeeded in educating her seven young children single-handed" (TLF, 2015a, p.1).

The purpose of this body and its activities "are to promote the welfare and economic empowerment of disadvantaged widows and education of their children. The Foundation currently makes grants to its sister charity in India, the Shrimati Pushpa Wati Loomba Memorial Foundation, to fulfill its aforesaid aims and the sister charity distributes funds which support widows and their children in India" (TLF, 2015a, p. 1). Besides, the Trustees have been assisting in promoting the fundamental freedoms and human rights of widows globally. Also, the children of widows around the world are partakers through advocacy (TLF, 2015a).

This organization has educated over 10,000 children of poor widows and supported over 60,000 of their family members across 29 states in India (TLF, 2015b). The body has also succeeded in providing "poor widows a two-months training in tailoring and a foot operated sewing machine on successful completion of the course, to help them support their family through dignified livelihood", (p. 1 of the above).

The Loomba Foundation has been "working with other NGO partners on livelihood programmes in the Middle East, Sub-Saharan Africa and South Asia. The livelihoods model the Foundation used was to provide the means for widows to start small businesses, which comprised skills training in a trade followed by business management skills and then provision of micro-credit loans and grants" (TLF, 2015c, p. 1).

\subsection{Examination of Research on the Emerging Concepts of Widow Support Groups in Nigeria}

As indicated above, several NGOs that are committed to the welfare of the less privileged are many in developed nations than Third World societies. Further to that, the impacts of these organisations on the lives of the masses in advanced countries may not be compared with the existing ones in Third World societies.

In Nigeria, despite the selfishness of the elite class and their nonchalant attitudes to the plight of the poor, few persons are still committed to assisting them. Thus, some widows supporting groups are in existence in Nigeria Emewu, (2008) but the activities of such groups and their impacts in the lives of widows have not been explored in academic literature. It is on this note that this section presents some of the existing widow's supporting groups in Nigeria and their efforts in making life comfortable for the widows.

\subsubsection{Widow Care Foundation in Nigeria}

The above mentioned supporting group is a Non-Governmental Organization (NGO) established in 1994 in Abakaliki, Southeast Nigeria with the aim of assisting the widows in all spheres of life (Emewu, 2008).

To ensure the success of this organization, the founder established Widow Care Foundation Headquarters in order to adequately attend to the needs of widows. Emewu $(2008$, p. 1) described the Widow Care Foundation as a "dream hatched to fill the void in the life of widows by taking on the role of their reliable friend". Through the Centre, 48 erstwhile homeless widows now have their own homes; modern houses with facilities provided while over 50 widows have been trained and employed by the Centre in various vocational skills: sewing and craft making. It was also reported by Emewu (2008) that, The Widow Care Centre/Foundation assists widows specifically in area of health challenge.

However, it should be noted that activities of this group is limited to Abakaliki, southeast geo-political zone of Nigeria. Thus, it is most likely that widows in other geo-political zones of the country may not be able to benefit from the 
organization. Given this flaw, another widow supporting group located in Lagos, Southwest geo-political zone of the country is discussed below:

\subsubsection{Tina Sam Ibekwe Foundation (TSIF)}

This is yet another NGO established to provide succor for widows. It was established in Lagos, southwest Nigeria in the year 2006 (Ibekwe 2009).

The aim of this NGO is to provide humanitarian services to widows, especially the needy and less-privileged among them. TSIF has been achieving its aim through donation from the founder. The fund provided so far has been used to buy some basic needs such as food, clothing for the widows. Also, it has been utilized to provide accommodation and scholarship for their children's education (Ibekwe, 2009).

In respect of the achievement of this foundation since the inception, Ibekwe (2009) categorically stated that not less than 200 widows and indigent people have benefitted immensely from the foundation. However, the impact of the TSIF is restricted to a few widows in Lagos metropolis and ignored numerous widows living in abject poverty in Northern Nigeria. Given this gap in knowledge, another widow supporting group based in Northern Nigeria is discussed below:

\subsubsection{Bounty Food for Hunger Relief Initiative (BFHRI)}

BFHRI is another NGO established to bring succor to widows in Northern Nigeria. According to Onche (2008), some widows from Abuja and Nassarawa State have benefited from this NGO in term of food items, jobs, and free training in adult education. Onche, (2008) argues further that the gesture by BFHRI no doubt indicates that the level of awareness and social supports given to widows has increased in the North. Although, BFHRI has created awareness and granted social support to widows in Abuja and Nassarawa state, but it fails to fight or campaign against all forms of discrimination against widows in these regions. Based on the above flaw in knowledge, another NGO that deals with advancing women's rights, not only in Nigeria by at global level is considered appropriate for this study. This is discussed below:

\subsubsection{Women's Right Advancement and Protection Alternatives (WRAPA)}

WRAPA is a registered, non-governmental organization established in Abuja, Northern Nigeria in 2006. The organization is being funded by the MacArthur Foundation (WRAPA, 2015).

As a body charged with the responsibility of advancing women's rights globally, WRAPA is currently one of the leading advocates of women liberation. The Abuja Coordinator of WRAPA, Mrs. Rabi Abdullahi described the need for legal reforms to support the elimination of all forms of gender violence including rape, female genital mutilation (FGM) and widowhood rites that erode the dignity of women (WRAPA, 2015).

This author also advances that, WRAPA is committed to fighting against all sort of violence affecting women with the aim of ensuring a drastic reduction in the alarming rate of gender-based violence in contemporary Nigeria.

In addition to the above, the NGO usually make provision for television programmes and materials from both the print and electronic media to show the plight of African widows and the need for urgent intervention (WRAPA, 2015). For instance, indigenous films: Till Death do us part, The Agony of Widows and Widows under the umbrella body of home movies producers in Nigeria, Nollywood, are few cases in which widows' plights WRAPA, (2015) are shown by WRAPA officials to the affected women.

Further to that, the popular television programme-Hands of Love anchored by Pastor Gina Harry, that exposes viewers to the ugly situation faced by most widows in Nigeria has equally been explored to assist widow (WRAPA, 2015).

However, WRAPA and other NGOs discussed in this section have contributed in one way or the other to making life easy for the widows, however, it is not certain if the impact of these organizations are felt among the widows in the study area. Therefore, the present study recommends another study to address this problem in the study area.

Dwelling on the above discussed widows supporting groups in both developed and Third world countries, a line distinction could be drawn between the two. While some of the groups in developed nations have spread to different continents of the world with great impacts, the influence of widows supporting groups in Nigeria is restricted to certain locations in the country. In fact, the influence of some of the NGOs in developed nations on Nigerian widows is seems to be greater than many indigenous NGOs in the country. 


\subsection{Theoretical Underpinnings}

In the past and in recent times, feminist theories have emerged in the literature to explain women's precarious situations worldwide. Most of these articles blame women position on cultural factors. Our focus in this article however hinges on Liberal Feminist Theory (LFT).

The theory is a reaction to Marxist or socialist feminism. Scholars in this paradigm strongly believe that only democratic process should be changed in the society while ardent supporters of the Liberal feminism contend against this viewpoint and argued that materials which can be used to ensure a change of position for women is more important that democratic process. In that wise, a change in the democratic process alone is not enough to change women situations; other resources should be harnessed in ensuring a meaningful change of women's pathetic situations in the society. Scholars such as (Rossi, 1988; Hooks, 1984; Abbey, 2013; Anderson, 2013; Barclay, 2013) subscribe to this paradigm.

The origin of the LFT is traceable to the participation of women in the Women's Suffrage Parade of 1913. Participants in that historic parade took a liberal feminist approach by using their democratic right to protest and to promote women's rights (Scarince, 2015). In 1920, the U.S. Congress considered women's position in 1913 parade and ratified the $19^{\text {th }}$ Amendment to the Constitution, which gave women the right to vote.

Central to LFT is the idea that individuals need to use their own abilities and the democratic process to help women and men become more equal in the eyes of the law, in society and in the workplace Scarince, (2015), by organizing women into larger groups for public speaking in favour of women at a higher level, lobbying legislators and raising awareness of issues affecting women. In other words, the paradigm is a particular approach to achieving equality between men and women Scarince (2015), using the power of different persons to alter discriminatory practices against women (Scarince, 2015).

Moreover, the idea that birth LFT is also hinged on customary and legal practices. These are regarded as tools that have actively contributed to women's discrimination in the society. Hence, "female subordination is rooted in a set of customary and legal constraints that blocks women's entrance to and success in the so-called public world" (Wikipedia, the Free Encyclopaedia, 2015, p. 1). Given this, it is necessary to strive for sexual equality via down-to-earth political and legal reforms (Tong, 1989 cited in Wikipedia, the Free Encyclopaedia, 2015)

The relevance of LFT is rooted in the high level of discrimination against women in the past and in the present age globally. The level of women's subjugation, in the present age, in many underdeveloped societies, in spite of the wave of modernisation and globalisation spreading across nations of the world resulting in meaningful changes in all spheres of life is a concern to scholars of development. Why? It is because while many obnoxious traditions and customs such as human sacrifice, killing of twin babies, people with hunch back, albinos have been successfully eradicated, no meaningful change has been recorded in women's position in spite of several articles, treaties and laws passed to ensure amelioration of women's precarious situations. This include, forcing women to sleep with dead body of their husbands, drinking the water used to bath their dead husbands, scrapping their hairs, forcing women to birth in the stream in the still of the night etc. It seems that the culture that is largely responsible for this is gain ground on a daily basis. Therefore, the theory provides a fertile ground for explaining the social life reality of the plight of widows in Nigeria today.

However, the argument of liberal feminism in support of gender equality is well understood, but scholars in this school of thought must have forgotten that God is a father of purpose. Thus, he created male and female differently but for the betterment of human race. At creation, God made a woman to be the help meet of man (Genesis 2:18) and not to have the same status with him. Thus, an attempt to equate gender could be perceived as obstructing the plan and purpose of God for humanity and it could be an exercise in futility. Perhaps, that might have been the major reason why the agitation for gender equality has never yielded any significant improvement. No one can work again God's plan and succeed.

Although, this paper is not in support of women subjugation, instead, the paper advocates the removal of every obnoxious cultural practice targeted against women and it replacement with different programmes that will reduce their suffering to the barest minimum. There is a need to empower women in all spheres of life. This could reduce their suffering and the attention of widows supporting groups on them during widowhood.

\section{Methods of Data Collection}

This study employed a case study and an ex-post facto design. Widows in Ota represented the population of this study. The population is estimated at 527,242, a little over half a million (National Population Commission, 2006). The Projected population (Pn) of Ota by this year 2010 is 612,068 about $2,000,000$. Out of this population, a sample of 942 widows was randomly selected for this study. 
Instruments used to collect data for this study were survey questionnaire, in-depth interview guide and observation guide.

The survey questionnaire containing both open and closed-ended questions was designed to elicit data from respondents. The twenty-five-question instrument was divided into three sections:

- Section A comprised of socio-economic and demographic characteristics of respondents.

- Section B centred on specific questions on widowhood practices observed and their coping strategies.

- The last section included questions on available support groups and types of assistance they received during and after widowhood.

The survey was complemented with In-depth interview of selected widows. The in-depth guide adopted for the study followed the pattern of the questionnaire.

Under observation guideline, the researcher set out to observe the respondents' general outward appearance, housing facilities, family size and willingness to re-marry.

The procedure for data collection resulted in the need to arrange informal meetings with major stakeholders (traditional rulers, religious leaders, heads of families/households etc). This often necessitated repeated visits to the study sites due to the busy schedule of the respondents. Because most of the respondents were illiterates, the questionnaire was administered with the assistance of trained researchers using the face to face method of question and response. The remaining questionnaire was self-administered to the literate among the sample.

An in-depth interview guide was utilized to elicit responses from the traditional rulers, religious leaders, heads of families/households and some elderly members of the communities who had useful information relevant to the research topic. Furthermore, observation of housing facilities, size of respondents' family vis-a-vis the living conditions and infrastructures available to the wellbeing of the widows being studied was made by the principal researcher.

The study was conducted using the following statistical methods - Out of the 997 questionnaires administered, $90 \%$ was useable for analysis.

Both quantitative and qualitative methods of data analyses were utilized in the study. The questionnaire was analysed using simple percentages and frequency tables. The in-depth interview and key informant data was found very useful as some views on the research questions were fully expressed by the widows and other respondents sampled. Some quotes from the respondents were brought to the fore and critically analysed in this paper.

\subsection{Analysis of the Objectives of the Study}

Table 1: Type of Support Received by Widows'

\begin{tabular}{|c|l|c|c|}
\hline S/N & Type of support received & Frequency & Percentage \\
\hline 1 & Cash and kind & 135 & 14.3 \\
2 & Visitation and goodwill & 6 & 0.6 \\
3 & Prayers and emotional support & 55 & 5.8 \\
4 & No form of support & 746 & 79.1 \\
\hline & Total & 942 & 100.0 \\
\hline
\end{tabular}

Source: Field work, 2016

Table 1 shows that majority of the widows did not receive any form of support (79.1\%). According the widows sampled, the closest support they enjoyed was in form of cash and kind (14.3\%). Below is the view shared by a respondent during the in-depth interview conduction?

"Due to the economic problems these days, most families with genuine intentions to assist are unable to cater for the widow. Women should double their effort rather than wait to receive supports or inherit property. There are women that are breadwinners today. The idea of complete house wife should be discouraged because no one knows when death will come".

According to another respondent during the key informant interview:

"If any, the extent of assistance and supports given to the widow during and after widowhood depends on her character. Good character is key. If the widow has a good character, she will not suffer. The extended family will go the extra mile to ensure that the widow and her children do not suffer lack". 
According to the respondents, some of the cash and kind supports received were in the form of school fees/apprenticeship training, food items, and provision of accommodation. Other supports received can be classified as health support (off-setting medical bills for the widows during health challenge).

Majority of the widows did not receive any form of support (79.1\%). The absence of supports from immediate family members, friends and other sources was due to the current financial crises and economic meltdown which increased hardship in the society. In the words of a 72-year-old Muslim widow interviewed in Ota during the fieldwork, "Those with genuine intention to assist the widows are unable to because of biting economic situation and hardship in the country".

Here is the view expressed by another widow of middle-aged category from a polygynous marriage: "Our husband's relatives have their own problems especially with the present economic situation in the country. Nobody will leave his/her own responsibilities and take care of your own. All I can say is that we have family members but none is willing or capable of helping us".

Table 2: Effects of Educational Attainment on Widows' Wellbeing.

\begin{tabular}{|l|c|c|c|c|c|}
\hline \multirow{2}{*}{ Opinion on wellbeing } & \multicolumn{5}{|c|}{ Highest level of education attained } \\
\cline { 2 - 6 } & No schooling & Primary & Secondary & Tertiary & Total \\
\hline Yes (coping) & $335(59.3)$ & $137(59.1)$ & $51(46.4)$ & $5(14.3)$ & $528(100.0)$ \\
No (Not coping) & $230(40.7)$ & $95(40.9)$ & $59(53.6)$ & $30(85.7)$ & $414(100.0)$ \\
\hline Total & $565(100.0)$ & $232(100.0)$ & $110(100.0)$ & $35(100.0)$ & $942(100.0)$ \\
\hline
\end{tabular}

Source: Field work, 2016

Table 2 suggests that educational attainment is inversely proportional to widows' well being. In other words, widows with higher educational attainment have lesser coping experience while those with low schooling seem to be coping better. $40.7 \%$ of the illiterate widows indicated they were not coping as against $85.7 \%$ literate widows who indicated they were not coping.

Dwelling on Table 2, educational attainment was found to be inversely proportional to widows' wellbeing. On first consideration this sounded strange as logic seems to suggest that widows with better educational attainment should experience better life and well-being, However, it appears that the more people are educated the more they tend to isolate themselves from relatives and friends, hence they stand the risk of suffering lack of social support in times of crisis. This apparently explains the finding here of educational attainment being inversely proportional to widows wellbeing.

Table 3: Effect of Support Received on Widows 'Wellbeing

\begin{tabular}{|l|c|c|}
\hline Effect of support received & Frequency & $\%$ \\
\hline Positive effect & 135 & 14.3 \\
Negative effect & 61 & 6.4 \\
No effect at all & 746 & 79.1 \\
\hline Total & 942 & 100.0 \\
\hline
\end{tabular}

Source: Field work, 2016

Deducing from Table 3, $79.1 \%$ of respondents in this sample said that the support received from people was not effective while about $14.3 \%$ claimed that the support positively affected their lives. Lastly, $6.4 \%$ claimed that the support they received was on the negative side.

Findings from majority of the respondents in addition to personal observation indicated that the support received had little or no effect on the widows wellbeing in the study area. The support received by the few widows does not seem to translate into their wellbeing.

Among the reasons adduced for this is the fact that the volume of support is meagre comparable to the needs of the widows. Apart from this, the supply of available support is not regular. Often time, the support does not meet the actual need of the widow. For instance, a widow may require cash and not food stuff but is offered a particular food stuff she does not eat or lack. Ultimately, the purpose of the earlier food donation is defeated. 
The absence of a well-structured support groups charged with the responsibility of providing support for the widows' wellbeing in Ota (the study location), could also be a contributing factor. There seems to be no government agency or NGO, be it at the local, state or federal level, directly or indirectly responsible to the widows in terms of support in Ota. In other worlds, activities of NGOs such as the Widow Care Centre in Abakaliki, south-eastern Nigeria, Bounty Food for Hunger Relief Initiative (BHFRI) in Northern Nigeria, Tina Ibekwe Foundation in Lagos and WRAPA located in Abuja established to advance the cause of the widows have not been able to impact positively on widows in Ota Metropolis.

\subsection{Summary of the Major Findings}

The study discovered that widows without any schooling accounted for the highest proportion (59.3\%) of the sample. Moreover, the study found that majority of the widows (79.1\%) did not receive any form of support and for those who received support, membership and the level of commitment of the widow in their religious circle was a major determinant for the kind and quality of supports received. Further to the above, the study found the absence of a well-structured support group charged with the responsibility of providing support for the widows' wellbeing in Ota (the study location). Lastly, the study discovered that educational attainment is inversely proportional to widows' well-being in the study area.

\subsection{Limitations of the Study}

This study is limited by the non-availability of existing databank on widows in the study area. This is in addition to the absence of widows' centres in the study location where well-meaning individuals, groups, government officials and nongovernmental organizations and others, with genuine intention for support and research on widows can be accessed.

This challenge constitutes a major problem for the study. Relying on data from individuals (widows and nonwidows) for the study is grossly insufficient. Many of the sensitive questions were ignored by respondents especially the widows who saw the questions raised in the study reminded them about their past horrible widowhood experiences. It was observed during the fieldwork that some widows sampled became emotional and busted into tears during the data collection exercise.

However, the multiple methods of (Survey, In-depth and Key Informant Interview) engaged by the researcher yielded some interesting results on the basis of which suggestions and recommendations are made for the study.

\section{Recommendations}

Widows like other disadvantaged and insecure groups in many societies require one form of support or the other for their wellbeing. Cash, clothing, food stuff, shelter or non-material items (emotional support, counselling, prayers from religious groups (churches, mosque or brethren) or other sources such as individuals, groups, relatives, friends, neighbours, colleagues and others could be used. Overall, the amount of support received by widows from religious and non-religious sources, family, friends, relatives' seem to be decreasing these days. In some cases, it is practically non-existent due to the present economic meltdown and hardship experienced by many people in the society (George, 2010). It is against this premise that the study proposes the following recommendations:

1. There is the need for government at all levels (local, state and federal) to be more sensitive to the plight of widows in the society. Budgetary allocation to support widows' wellbeing especially in the rural areas is hereby suggested. The aged widows who are sickly and cannot afford to work or engage in any meaningful source of livelihood may be placed on monthly stipend coordinated at the community or local government levels ably supervised by the community leaders/traditional rulers who are able to identify the widows in need of such supports.

2. For widows' security to be guaranteed in contemporary societies; there is need for widows' empowerment in terms of providing them access to a means of livelihood. The aged widows who are unable to acquire education can be empowered in their trading activities or vocations through training in areas such as tailoring, bakery, bead making, fish farming, grass cutter farming, snail farming, food processing and packaging etc to earn additional income. This is in addition to the provision of soft loans to aid their small scale petty trading and scholarship for their children's education.

3. The need for widows' database or research centre to aid extensive research on widows' plights and issues that pose challenges to them is crucial. Besides, it will assist in planning for widows' wellbeing. 


\section{Concluding Remarks}

The main thrust of this paper was to examine the role of support groups, the different types available and the form of assistance they render to widows in ensuring their wellbeing. The study further investigated the provision of supports to widows, be it in the form of cash or kind and concluded that more supports were received during the widowhood period when the widows were confined indoors. The supports that came from private and family sources were more regular and consistent. But after the expiration of the widowhood period, the amount of supports received began to decrease and came once in a while especially during festivities (Easter, Christmas and Muslim celebrations). After the performance of the last mourning rites at the expiration of the widowhood period, widows are expected to go about their normal activities in order to fend for themselves.

\section{References}

Abbey, R. (2013). 'Biography of a Bibliography: Three Decades of Feminist Response to Rawls.' In Abbey (2013).

Adeyemo, C. W. (2014). Assessing the Effects of Widowhood on Children Education in Southwestern, Nigeria. Journal of Education and Practice, 5(11): 48-53

Andelman, D. A. (2007). The World's Most Corrupt Countries. Forbes. Available on http://www.forbes.com/2007/04/03/corruptioncountries-nations-biz-07caphosp-cx_da_0403corrupt.html. Retrieved on July 25, 2016

Anderson, E. (2009). 'Toward a Non-Ideal, Relational Methodology for Political Philosophy: Comments on Schwarzman's Challenging Liberalism.' Hypatia 24: 130-145.

Andrea-Teresa, (2010). Women: Backbone of the Family and Society. Available on http://www.talkingculturaldiversity.com/index.php/ 2010/04/25/women-backbone-of-the-family-and-society/

African Leadership. (2012). Holocaust: The Root of Failure in Africa. Available on http://www.africanholocaust.net/news_ah/african leadership.html. Accessed on November 10, 2015.

Age Concern, (1999). Debate of the Age Conference: Millennium Papers. London, Age Concern.

Annie, K. (28 November 2006). "Pudsey's worst nightmare". The Guardian (London). Retrieved 28 April 2010

Barclay, Linda (2013). 'Liberal Daddy Quotas: Why Men Should Take Care of the Children, and How Liberals Can Get Them to Do It.' Hypatia 28:163-178

BBC Children in Need (2012). "BBC Children in Need Annual Report and Accounts Nine Months to 30 June 2012" (PDF). Charity Commission for England and Wales. p. 4. Retrieved 16 November 2014.

Blair, C. (2010). Over 115 million widows worldwide live in poverty. Available on http://usatoday30.usatoday.com/news/health/2010-0623-un-widows-poverty_N.htm. Accessed on November 12, 2015.

Brunnstrom, D and Mason, J. (2015). Modi calls for climate change agenda that helps developing countries. Reuters. Avalable on http://www.reuters.com/article/2015/09/29/us-un-assembly-obama-modi-idUSKCNORS23020150929

Callahan, D. (2016). Mark Zuckerberg's \$2.5 Billion Foundation, Inside Philanthropy. Avalable on http://www.insidephilan thropy.com/home/2014/7/25/mark-zuckerbergs-25-billion-foundation.html

Clark, R. (2007). "Read the small print before the next Comic Relief". The Spectator. p. 16. Retrieved 17 December 2013.

Daily Mail (2007) "Terry Wogan waives his $£ 9,000$ fee for Children in Need". Daily Mail (London). 15 November 2007. Retrieved 19 November 2011.

Daniel, A. (2015). Factors Influencing Low Level of Women Participation in Literacy Programme in Maiha Local Government Area of Adamawa State. Journal of Education and Practice, 6(15): 183-188

Durojaye, E. (2013) "Woman, but not human": widowhood practices and human rights violations in Nigeria. Civilistica.com. Rio de Janeiro, a. 2, n. 3, jul.-set./2013. Disponível em: <http://civilistica.com/woman-but-not-human/>. Data de acesso.

Emewu, I. (2008)."Beyond Office Gimmicks: Mrs Egwu Expands NGO after Office, Completes 48 Houses for Widows, plans to build more" in Saturday Sun, June 1, p.22.

George, T. O. (2010). Widowhood and Property Inheritance among the Awori of Ogun State, Nigeria" Unpublished PhD Thesis Department of Sociology. Covenant University, Ota,

George, T. O., Omonijo, D. O., Uche, O. C., Anyaegbunam, M. C., and Shaibu, A. O. (2016). Widows' Socio-Demographic Characteristics and Observance of Widowhood Rites Among The Aworis, Southwest Nigeria. Mediterranean Journal of Social Sciences. 7(4): 317- 329, Doi:10.5901/mjss.2016.v7n4p

Hooks, B. (1984). "Feminist Theory: From Margin to Center" Cambridge, MA: South End Press.

Ibekwe, T.S. (2009). "Giving Succour to Widows is my Life" in Daily Sun Tuesday, February 10, 2009 Pp. 26.

Light, N. (2014). Widowed Persons Support Group marks 30 years of helping grieving spouses. Dallas Morning News, December, 25, 2015. Available on http://www.dallasnews.com/news/community-news/park-cities/headlines/20141024-widowed-persons-supportgroup-marks-30-years-of-helping-grieving-spouses.ece. Assessed on December 26. 2015.

Millennium Development Goals, (2015). 60 Ways United nations make a Difference. Available on http://www.un.org/en/un60/60 ways/ec_dev.shtml

National Population Commission, (2006). A list of tables from analysis of the 2006 Census are available for download by clicking on titles of interest. Available on http://www.population.gov.ng/index.php/censuses. Accessed on Dec. 31, 2015. 
National Widowers Organisation, (2016). Where Can I Find Men's Support Groups? Available on http://www.nationalwidowers.org/ support-groups/\#.V5Nq67grLIU

Newham Grass Root Fund (2015). Available on http://newham.com/page/community/community_groups_in_newham_to_benefit_from grassroots_grant/473,10,0,0,0.html.

Myers, $\bar{P}$. (2012). Child Development Institute. Available on http://childdevelopmentinfo.com/authors/pammysue/

New Covenant for Widows, (2016). Available on http://www.newcovenant.com/home.

New York Times (2016). Bill and Melinda Gates Foundation. Available on http://www.nytimes.com/topic/organization/bill-and-melindagates-foundation

Obiora, L. A. (1997). 'Feminism, Globalisation and Culture: after Beijing', Indiana Journal of Global Legal Studies, 4, 355-406.

Ogbeidi, M. M. (2012). Political Leadership and Corruption in Nigeria Since 1960: A Socio-economic Analysis. Journal of Nigeria Studies, $1(2): 2-25$.

Okonkwo, R. (2007). Corruption in Nigeria: A Historical Perspective (1947 - 2002). In African Unchained. Retrieved from http://africaunchained.blogspot.com/2007/09/corruption-in-nigeriahistorical.html.

Omonijo, D. O and Nnedum, O.O.U. (2012). Impacts of Societal Prejudice on Attainment of Life/Personal Goals of Physically Challenged Persons in Nigeria. International Research Journal of Humanities, 4(5):1-13

Onche, C. (2008). "Widows Appreciate NGO" Leadership December 31'st 2008, Pg 1.

Oyeniyi, A. and Ayodeji, I. (2010). 'Widowhood practices among the Yorubas of southwest Nigeria: are there differences in what women experience due to their status?', Gender and Behaviour, 8, 3152-67.

Owen. M. (2000). A World of Widows", paper presented to UNIFEM Panel on Widows and Widowhood: Myths and Realities during the Beijing +5 special session, June

Potash, B. (1986). "Widows in Africa: An Introduction" in B. Potash (ed.) Widows in African Societies: Choices and Constraints Stanford University press, Stanford, California. ican Studies 43, 12-33.

Rossi, Alice S (1988). The Feminist papers: from Adams to de Beauvoir. Northeastern. p. 25.

Rostow, W. W. (1960)."The Five Stages of Growth-A Summary". The Stages of Economic Growth: A Non-Communist Manifesto. Cambridge: Cambridge University Press. pp. 4-16.

Samuel, G. C. E. (2011). 'Emergent issues on widowhood practices in Igbo culture: between the video screen and reality', Unizik Journal of Arts and Humanities (UJAH), 8, 184-93.

Scarman Trust, (2015). Best Community Service \& Non Profit in Brighton. Available from http://www.yelp.co.uk/c/brighton/nonprofit

Scarince, C. (2015). Liberal Feminism: Definition \& Theory. Study.com. Available on http://study.com/academy/lesson/liberal-feminismdefinition-theory-quiz.html

Sesay, A. and Odebiyi eds. (1998). Nigerian Women in Society and Development, Ibadan: Dokun Publishing House.

Sossou, M. A. (2002). 'Widowhood practices in West Africa: the silent victims', International Journal of Social Welfare, 11, 201-09.

Ssenyonjo, M. (2007). 'Culture and human rights of women in Africa: between light and shadow', Journal of African Law, 51, 39-67.

Steele, J. (2000). Corruption in the third world is our problem. The Guardian. Available on https://www.theguardian.com/world/ 2000/dec/13/globalisation.comment. Retrieved on July 25, 2016

Tamale, S. (2004). 'Gender trauma in Africa: enhancing women's links to resources', Journal of African Law, 48, 50-61.

Tamale, S. (2008). 'The right to culture and the culture of rights: a critical perspective on women's sexual rights in Africa', Feminist Legal Studies $16,47-69$.

The World's Women (2000): Trends and S t a t i s t i c s (United Nations publication, Sales No. E.00. XVII (14).

The Loomba Foundation, (2015a). Caring for Widows Around The World (Who-We-Are). Available on http://theloombafoundation.org/ who-we-are/. Assessed on December 25

The Loomba Foundation, (2015b). Caring for Widows Around The World (Our Work). Available on http://theloombafoundation.org/ourworkl. Assessed on December 25

The Loomba Foundation, (2015c). Caring for Widows Around The World (Empowerment). Available on http://theloombafoundation. org/empowerment/. Assessed on December 25,

Trivedi J.K., Sareen H., Dhyani M., (2009), Psychological Aspects of Widowhood and Divorce. In: Some Issues in Women's Studies, and Other Essays (A.R. Singh and S.A. Singh eds.), MSM, 7, Jan: 37-49

UK International Development Committee, Women and Development, (1999). Seventh Report. London: The Stationery Office.

United Nations Development Programme, (2015). Women and the Sustainable Development Goals. Available on http://int.search.tb.ask. $\mathrm{com} / \mathrm{search} / G$ Gmain.jhtml?searchfor=United+Nations+Development+Programme\%2C+2015\&st=kwd\&ptb=D684CEDD-DF664044-BE45-5CFACA57D94B\&n=780c23c8\&ind=2014061512\&p2=^XQ^xdm177^YYA^ng\&si=CKHAo9no74CFSoCwwoddEwAhA

UN Division for the Advancement of Women. Women (2000). Widowhood: invisible women, secluded or excluded. 2001. [Accessed 20 March, 2008]. Available at: http://www.un.org/womenwatch/daw/public/wom_Dec\%2001\%20single\%20pg.pdf .

Vanguard, (2015). The Caliphate, The Emir and Nigeria's Master Race. Available on Read more at: http://www.vanguardngr.com/2015/ 12/the-caliphate-the-emir-and-nigerias-master-race/

Way Widowed and Young, (2014). Bereavement Support. Available on https://www.widowedandyoung.org.uk/bereavement-support/. Retrieved on July 23, 2016.

West, A. (2003). How Africans Leaders Underdeveloped Africa. Guardian, Daily

Wadri, P. (2004). Illiteracy is Africa's Most Virulent Disease, Especially For Women. In Africa. Available on http://livinginafrica.blogspot. 
com.ng/2004/07/illiteracy-is-africas-most-virulent.html. Retrieved on June 24, 2016

Widow Care Worldwide, (2015) http://widowcareworldwide.org/wp-content/uploads/2015/07/WCW-7.jpg

Widows Connection, (2014). Widows helping Widows Rebuild their lives. Available on http://wconnection.org/. Retrieved on July 23, 2016

Wikipedia, the Free Encyclopaedia, (2015) . Liberal feminism. Available on https://en.wikipedia.org/wiki/Liberal_feminism

Wogu, I. A. P., Duruji, M and Ibietan, J. (2013). Greater Aid as the Panacea to Third World Development Challenges: a Critical Analysis. Journal of Economics and Sustainable Development, 4(16): 85-96

World Bank, (2000). Voices of the Poor. Case Study 9: Widows (Washington, D.C., World Bank

World Bank, (2013). Corruption is "Public Enemy Number One" in Developing Countries, says World Bank Group President Kim. Available on http://www.worldbank.org/en/news/press-release/2013/12/19/corruption-developing-countries-world-bank-grouppresident-kim. Retrieved on July 25, 2016

Women's Rights (2007). Women's Right in Turkey: Improvements Still Needed," European Parliament Press Service, at http://www.europarl.europa.eu/comparl/femm/press/2007/20070213_press_release_en.pdf.

Human Rights Watch, (2006). "A Question of Security: Violence Against Palestinian Women and Girls," November 2006, http://www.hrw.org/reports/2006/opt1106/7.htm\#_Toc148851357. See also Freedom House, "Palestine (Palestinian Authority and Israeli-Occupied Territories)," 